\title{
Metode Pembelajaran E-Learning Menggunakan Technology Acceptance Modelling (TAM) Untuk Pembelajaran Akuntansi Johandri Iqbal ${ }^{1}$, Arisman ${ }^{2}$
}

\author{
Program Studi Akuntansi, Politeknik Jambi, Jln. Lingkar Barat, Kel. Bagan Pete, Jambi, 36129
}

\section{A R T I C L E I N F O}

\section{Article history:}

Received 8 Oktober 2018

Revised 21 November 2018

Accepted 7 Desember 2018

\section{Key words:}

E-Learning, technology acceptance model (TAM), structural equation modeling (SEM)

\begin{abstract}
A B S T R A C T
This study develops E-learninglearning model. By applying E-learninglearning design, it facilitates lecturer and student to expand supporting course on their own. E-learningsystem design uses technology acceptance model concept (TAM) which is a technology and information system acceptance model will be used by the user. The construct in technology acceptance mode is perceived usefulness, perceived ease of use, attitude towards behavior, behavioral intention, and actual technology use. Hypothesis test used structural equation modeling (SEM). By testing the validity and reliability, Model fit criteria, Output Laten Variable coefficients, Output Indirect and total Effects, seven hypothesis which would be examined, five hypothesis are accepted and two hypothesis are rejected.
\end{abstract}

\section{INTRODUCTION}

Sistem pembelajaran e-learningmerupakan metode baru dalam proses belajar dan mengajar,perkembangan e-learningadalah dasar dan konsekuensi dari teknologi dan komunikasi.Melalui e-learningmahasiswa tidak perlu duduk diruangan kelas termasuk pengajar tidak perlu berdiri diruangan kelas untuk menerangkan pelajaran. Sistem e-learningadalah proses pembelajaran dalam dapat mempersingkat jadwal target waktu pembelajaran.

E-learningmerupakan bentuk metode pembelajaran yang dipersepsikan bersifat student centered. Sistem pembelajaran e-learningdalam pemanfaatannya dapat memotivasi peningkatan kualitas pembelajaran, kualitas aktivitas kemandirian mahasiswa, serta komunikasi antara dosen dengan mahasiswa. Perbandinganproses pembelajaran tatap muka dengan pembelajaran berbasis e-learningdapat dilihat pada tabel berikut ini:

Tabel 1.

Perbandingan Pembelajaran

\begin{tabular}{|c|l|l|}
\hline No & $\begin{array}{l}\text { Pembelajaran Tatap } \\
\text { Muka }\end{array}$ & $\begin{array}{c}\text { Pembelajaran } \\
\text { berbasis E-Learning }\end{array}$ \\
\hline 1 & $\begin{array}{l}\text { Adanya pertemuan } \\
\text { tatap muka }\end{array}$ & $\begin{array}{l}\text { Tidak memerlukan } \\
\text { tatap muka }\end{array}$ \\
\hline 2 & $\begin{array}{l}\text { Waktunya sesuai } \\
\text { jadwal }\end{array}$ & $\begin{array}{l}\text { Waktunya kapan } \\
\text { saja }\end{array}$ \\
\hline 3 & $\begin{array}{l}\text { Membutuhkan } \\
\text { ruangan kelas }\end{array}$ & $\begin{array}{l}\text { Tidak membutuhkan } \\
\text { ruangan kelas }\end{array}$ \\
\hline
\end{tabular}




\begin{tabular}{|c|l|l|}
\hline 4 & $\begin{array}{l}\text { Dominannya peran } \\
\text { dosen }\end{array}$ & $\begin{array}{l}\text { Dominannya peran } \\
\text { mahasiswa }\end{array}$ \\
\hline 5 & $\begin{array}{l}\text { Kemungkinan } \\
\text { mahasiswa pasif }\end{array}$ & Mahasiswa aktif \\
\hline 6 & $\begin{array}{l}\text { Adanya keterbatasan } \\
\text { waktu }\end{array}$ & $\begin{array}{l}\text { Tidak maja } \\
\text { keterbatasan waktu }\end{array}$ \\
\hline 7 & $\begin{array}{l}\text { Belajar mahasiswa } \\
\text { tergantung dosen dari }\end{array}$ & $\begin{array}{l}\text { Mahasiswa belajar } \\
\text { mandiri }\end{array}$ \\
\hline 8 & $\begin{array}{l}\text { Materi ajar dateri bisa update } \\
\text { dosen }\end{array}$ \\
\hline 9 & Guru adalah subyek & Siswa adalah subyek \\
\hline
\end{tabular}

Sumber: (Eko, 2011)

Perguruan tinggi sudah banyak yang merintis dan mengembangkan model pembelajaran berbasis e-learninguntuk mendukung sistem konvensional.Terobosanperguruan tinggi bertujuan untuk memanfaatkan teknologi informasi secara optimal dalam penyelenggaraan pendidikan. Salah satunya pemanfaatan jaringan internet didunia pendidikan adalah pengembangan sistem E-learningdengan Modular Object Oriented Dynamic Learning Environment (MOODLE)yang merupakan paket perangkat lunak dalam proses kegiatan belajar berbasis internet dan situs web yang menggunakan prinsip social constructionist pedagogy.

Pembelajaran

e-learningdalam

memanfaatkan teknologi informasi dalam proses mekanisme belajar dan mengajar memanfaatkan aplikasi moodle.Moodle salah satu aplikasi open source di bawah lisensi GNU, aplikasi moodle dapat diinstal di komputer dan sistem operasi apapun yang bisa menjalankan PHP dan mendukung database SQL.

Technology Acceptance Model (TAM) dikembangkan oleh Davis tahun 1985, model ini merupakan adaptasi dari model Theory of Reasoned Action (TRA) oleh Fishbein dan Ajzen, ada 2 konstruk dalam TAM yaitu kegunaan (perceived usefulness) dan kemudahan penggunaan (perceived ease of use). Konstrruk kegunaan didefinisikan sebagai tingkat dimana seseorang mempercayai bahwa menggunakan suatu sistem tertentu akan memaksimalkan kinerja mereka, sedangkan konstruk kemudahan penggunaan merupakan suatu kepercayaan dalam penggunaan suatu sitem tanpa diperlukan usaha yang keras(davis, 1985 dalam buku(Jogiyanto, 2008)). Untuk saat ini model TAM banyak dimodifikasi dengan ditambahkannya faktor-faktor eksternal yaitu self efficacy, complexity dan lack of time.Analisis pendekatan TAM digunakan untuk mengetahui faktor-faktor yang mempengaruhi dalam penggunaan e-learning. Politeknik Jambi belum memaanfaatkan TAM menjadi parameter untuk memberikan program e-learningpada proses belajar mengajar.

perkembangan teknologi informasi yang semakin pesat di era revolusi industri 4.0, kebutuhan akan suatu pembelajaran yang baru menjadi tidak terelakan lagi. Pada dasarnya $e$ learningsudah menjadi kebutuhan akan metode pembelajaran yang baru di Jurusan Akuntansi Politeknik Jambi.

Manfaat e-learninguntuk pembelajaran akuntansi membawa suasana baru dalam ragam pengembangan. Pemanfaatan e-learningdengan baik dapat meningkatkan hasil pembelajaran dengan maksimal. Beberapa manfaat dari eleraning pada pembelajaran akuntansi diantaranya adalah

1. E-learningmaka dapat mempersingkat waktu pembelajaran

2. E-learningmempermudah interaksi antara mahasiswa dengan dosen dan bahan materinya

3. Mahasiswa dapat saling berbagi informasi dan dapat mengakses bahan-bahan belajar setiap saat dan berulang-ulang, dengan demikian mahasisea lebih memantapkan penguasaan materi pembelajaran

4. Dengan e-learningproses pengembangan pengetahuan tidak hanya terjadi dalam ruangan kelas saja.

e-learningmenjadi solusi yang tepat bagi dunia pendidikan di Indonesia khusunya perguruan tinggi dalam pemerataan kesempatan belajar dan peningkatan mutu, manfaat $e$ learningpada program studi akuntansi politeknik jambi adalah

1. Fleksibilitas tenpat dan waktu, jika pembelajaran konvensional dikelas mengharuskan mahasiswa untuk hadir dikelas pada jam-jam tertentu, maka $e$ learningmemberikan fleksibilitas dalam memilih waktu dan tempat untuk mengakses pelajaran

2. Independent learning, e-learningmemberikan kesempatan bagi pembelajar untuk memegang kendali atas kesuksesan belajar masing-masing, artinyapembelajar diberi kebebasan untuk menentukan kapan akan mulai, kapanakan menyelesaikan, dan bagian mana dalam satu modul yang ingindipelajarinya terlebih dulu. Jika ia mengalami kesulitan, ia bisa 
mengulangulang lagi sampai ia merasa mampu memahami.

3. Banyak biaya yang bisa dihemat dari cara pembelajaran dengan e-learning. Secara finansial, biaya yang bisa dihemat, antara lain biayatransportasi ke tempat belajar dan akomodasi selama belajar, biayaadministrasi pengelolaan, penyediaan sarana dan fasilitas fisik untuk belajar

Penerapan e-learningdi program studi akuntansi pengguna utama e-learningadalah mahasiswa yang menurut pengamatan peneliti masih kurang dalam kemauannya untuk memanfaatkan e-learningOleh karena itu faktorfaktor yang mempengaruhi dalam penggunaan $e^{-}$ learningakan dianalisis dengan pendekatan Technology Acceptance Model (TAM).

Penelitian yang telah dilakukan berkaitan dengan pengukuran penerimaan menggunakan TAM terhadap sistem e-learningdiantaranya dilakukan oleh Flourensia, (2017) yang berjudul Analisis Penerimaan e-learningmenggunakan Technology Acceptance Model (TAM) yang hasil penelitiannya menunjukkan bahwa kemudahan penggunaan berpengaruh positif terhadap persepsi manfaat dan sikap penggunaan. Hal tersebut menunjukkan bahwa pengguna e-learningmerasa bahwa sistem tersebut mudah digunakan maka akan memberikan manfaat bagi mahasiswa dan mempengaruhi penerimaan terhadap $e$ learningtersebut.

Penelitian Surya Ade Saputera, (2017) berjudul analisis penerimaan sistem elearningmenggunakan technology acceptance model (TAM) hasil penelitiannya menunjukkan penggunaan teknologi atau Attitude Toward Using terhadap faktor penggunaan sesungguhnya atau Actual Usage memberikan makna bahwa semakin baik sikap dalam memutuskan untuk menggunakan e-learningmaka akan semakin tinggi adopsi sistem e-learning.

Berdasarkan uraian permasalahan diatas, maka perlu dilakukan penelitian "Metode Pembelajaran learningMenggunakanTechnology Acceptance Model (TAM)"tujuan penelitian ini untuk mengetahui faktor -faktor yang mempengaruhi keberhasilan pembelajaran e-learning dengan pendekatan Technology Acceptance Model (TAM), Mewujudkan keberhasilan penggunaan e-learning dalam proses belajar mengajar di Politeknik Jambi, dan meningkatkan menggunakan e-learningdalam proses belajar mengajar di Politeknik Jambi.

\section{THEORETICAL FRAMEWORK AND HYPOTHESES}

E-learning adalah pembelajaran denganmemanfaatkanteknologi elektronik sebagai sarana penyajian data distribusi informasi. Bisa berupa technology base learning seperti audio dan video atau web-base learning dengan bantuan perangkat computer dan internet. Pengertian $e$ learning paling umum dikemukan oleh (Clark, Colvin, Richard, \& Mayer, 2011) merupakan instruksi yang disampaikan dalam perangkat digital sebagai komputer atau perangkat mobile yang bertujuan untuk mendukung pembelajaran.

Menurut (Rusman, 2012) e-learning merupakan pembelajaran dengan menggunakan jasa bantuan perangkat elektronika.Jadi dalam pelaksanaannya e-learning menggunakan perangkat elektronika.Jadi dalam pelaksanaannya e-learning menggunakan perangkat komputer atau perangkat elektronik lainnya.

Definisi menurut (Rosenberg, 2002), Elearning merupakan salah satu pemanfaatan teknologi internet dalam penyampaian pembelajaran dalam jangkauan yang luas yang berlandaskan tiga kriteria yaitu:

1. E-learningmerupakan jaringan dengan kemampuan untuk memperbarui, menyimpan, mendistribusikan, dan membagi materi ajar atau informasi.

2. Pengiriman sampai ke pengguna terakhir melalui komputer dengan menggunakan teknologi internet yang standar.

3. Memfokuskan dasar pandangan yang paling luas tentang pembelajaran dibalik paradigma pembelajaran tradisional.

Sistem atau konsep pendidikan yang memanfaatkan teknologi informasi dalam proses belajar dan mengajar dapat disimpulkan merupakan pembelajaran e-learning. Jadi $e$ learningadalah sebuah proses pembelajaran yang berbasis elektronik dengan salah satu media yang digunakan adalah jaringan komputer yang terhubung ke internet.

Modular Object Oriented Dynamic Learning Environment atau disingkat Moodle merupakan salah satu LMS yang bersifat open sourceyang dikembangkan oleh Martin Dougiamas dan dapat diunduh secara gratis melalui situs http://moodle.org.Moodle merupakan perangkat lunak berbasis web yang memungkinkan instruktur, trainer dan pendidik untuk membuat course berbasis internet (Dvorak, 2011).(Surjono, 2013) menyatakan Moodle mendukung implementasi e-learningdengan paradigma terpadu 
dimana fitur penunjang pembelajaran dengan mudah dapat diakomodasi dalam suatu portal $e$ learning. Fitur-fiturdalam menunjang pembelajaran tersebut misalnya: tugas, kuis, komunikasi, kolaborasi serta fitur utama yang dapat mengunggah (upload) berbagai format materi pembelajaran.

Technology Acceptance Model

(TAM)pertamakali dikembangkan oleh (Davis, 1985 dalam buku (Jogiyanto, 2008)) kelebihan TAM yang paling penting adalah TAM merupakan model yang sederhana tapi valid.TAM merupakan suatu teori tentang penggunaan sistem teknologi informasi yang sangat berpengaruh, pada umumnya digunakan untuk menjelaskan penerimaan individu terhadap penggunaan sistem teknologi informasi.

Penerimaan pengguna dalam penggunaan sistem informasi dalam TAM dipengaruhi oleh dua konstruk, yaitu kegunaan (perceived usefulness) dan kemudahan penggunaan (perceived ease of use).Kedua konstruk tersebut merupakan perbedaan paling mencolok yang ada pada TAM, model TAM dapat dilihat pada gambar berikut:

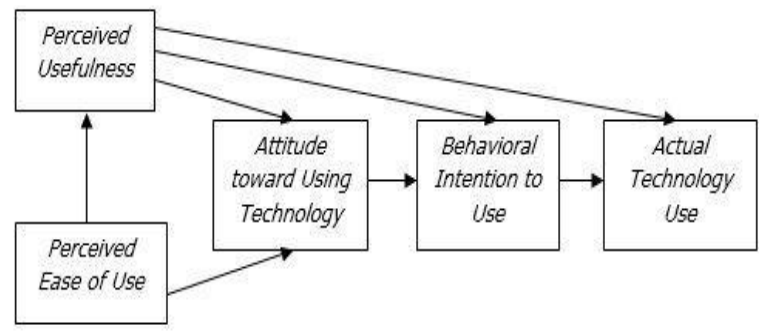

\section{Gambar 1Model TAM}

Sumber: Sistem Informasi Keperilakuan, 2008.

TAM memiliki 5 konstruk utama, yaitu:

1. Perceived usefulness (kegunaan)

2. Perceived ease of use (kemudahan penggunaan)

3. Attitude toward using technology (sikap)

4. Behavioral intention to use (perilaku)

5. Actual technology use (penggunaan teknologi sesungguhnya)

Sedangkan penjelasan konstruk sebagai berikutKonstruk pertama adalah perceived usefulness dari definisinya, merupakan suatu kepercayaan yang kegunannya tentang proses pengambilan keputusan. Dengan demikian jika seseorang merasa percaya bahwa sistem informasi berguna maka dia akan menggunakannya. Sebaliknya jika seseorang merasa percaya bahwa sistem informasi kurang berguna maka dia tidak akan menggunakannya.

Konstruk kedua adalah perceived ease of usedari definisinya, diketahui sebagai konstruk kemudahan penggunannyayang merupakan suatu kepercayaan tentang proses pengambilan keputusan. Jika seseorang merasa percaya bahwa sistem informasi mudah digunakan maka dia akan menggunakannya. Sebaliknya jika seseorang merasa percaya bahwa sistem informasi tidak mudah digunakan maka dia tidak akan menggunakannya.

Konstruk ketiga adalah attitude toward using technology yang selanjutnya disebut sikap. Sikap dapat didefinisikan sebagai perasaan dalam menggunakan sistem dari seseorang jika harus melakukan perilaku yang akan ditentukan.

Konstruk keempat adalah behavioral intention to use yang selanjutnya disebut intensi, intensi memiliki pengaruh pada penggunaan teknologi sesungguhnya serta dipengaruhi oleh sikap dan kegunaan.

Konstruk kelima adalah actual technology use yang selanjutnya disebut penggunaan teknologi sesungguhnya atau penggunaan.TAM mempunyai beberapa kelebihan. Kelebihankelebihan TAM sebagai berikut ini:

1. Merupakan model perilaku (behavior) yang bermanfaat untuk menjawab pertanyaan sistem teknologi informasi yang banyak gagal.

2. Model TAM telah diuji dengan banyak penelitian dan hasilnya menyimpulkan bahwa TAM merupakan model yang baik.

3. TAM merupakan model yang sederhana tetapi valid atau model parsimony (parsimonius).

Berdasarkan penelitian yang terdahulu yang telah dikemukan seperti kegunaan persepsi yang mana peneltian sebelumnya kegunaan persepsian mempengaruhi secara positif dan signifikan terhadap penggunaan sistem informasi (misalnya Davis, 2008; Chau, 1996) , penelitian-penelitian sebelumnya juga menunjukkan bahwa konstruk kemudahan penggunaan persepsian mempengaruhi kegunaan persepsian, sikap, niat dan penggunaan sesungguhnya, pada penelitian davis, 1989, sikap terhadap perilaku didefinisikan oleh davis, 1989, sebagai perasaan positif atau negative dari seseorang jika harus melakukan perilaku yang ditentukan, hasil penelitian-penelitian sebelumnya menunjukkan 
bahwa sikap ini berpengaruh secara positif ke niat perilaku. Hasil penelitian-penelitian sebelumnya menunjukkan bahwa niat perilaku (behavioral intention) merupakan prediksi yang baik dari penggunaan teknologi oleh pemakai sistem misalnya dalam penelitian yang dilakukan oleh davis, 1989; taylor dan Todd, 1995. maka hipotesis yang akan diuji dalam penelitian ini adalah sebagai berikut:

H1: Persepsi kemudahan penggunaan (Perceived Ease of Use) berpengaruh terhadap persepsi kegunaan (Perceived Usefullnes) pada penggunaan e-learningdi Politeknik Jambi

H2: Persepsi Kegunaan (Perceived Usefullness) berpengaruh positif terhadap sikap terhadap perilaku (Attitude Towards Using) penggunaan e-learning di Politeknik Jambi

H3: Persepsi kemudahan penggunaan (Perceived Ease of Use) berpengaruh terhadap sikap terhadap perilaku (Attitude Towards Using) pada penggunaan e-learning di Politeknik Jambi

H4: Sikap terhadap perilaku (Attitude Towards Using) berpengaruh terhadap niat perilaku (Behavioral Intention) pada penggunaan $e$ learning di Politeknik Jambi

H5:Persepsi kegunaan (Perceived Usefullnes) berpengaruh positif terhadap niat perilaku (behavioral Intention) penggunaan e-learning di Politeknik Jambi

H6: Niat perilaku (behavioral Intention) berpengaruh terhadap Penggunaan nyata sistem (Actual system usage) e-learning di Politeknik Jambi

H7:Persepsi Kegunaan (Perceived Usefullness) berpengaruh positif terhadap Penggunaan nyata sistem (Actual system usage) e-learning di Politeknik Jambi

\section{RESEARCH METHOD}

Peneltian ini dilaksanakan di Politeknik Jambi yang beralamat jalan Lingkar Barat 2 Lrg Veteran Rt 4 Kel.. Bagan Pete Kec. Alam Barajo Kota.Jambi.Populasi di penelitian ini adalah user sistem E-learningPopulasi dipenelitian ini adalah user sistem e-learning pada program studi Akuntansi Politeknik Jambi, yang mana pembelajaran akuntansinya menerapakan sistem perkuliahan dengan matakuliah $60 \%$ Tatap muka dan $40 \%$ e-learning. Sistem e-learning yang digunakan adalah sistem Moodle.

Pengumpulan data dilakukan dengan metode kuesioner yang akan diisi oleh mahasiswa pengguna sistem e-learning. Periode pengumpulan kuesioner selama 2 minggu dengan menggunakan kuesioner online yaitu menggunakan google form.Kuesinoer dibagikan secara online melalui ketua program studi dan diteruskan kemahasiswanya.Berdasarkan teori yang telah dibahas pada tinjauan pustaka, definisi operasional masing-masing variabel berdasarkan Jogiyanto (2008) penelitian ini dijabarkan sebagai berikut

1. Perceived usefulness

Perceived usefulness didefinisikan seajuah mana seorang percaya bahwa menggunakan suatu teknologi akan meningkatkan kinerja.

2. Perceived ease of use

Perceived ease of use didefiniskan sejauh mana seseorang percaya bahwa menggunakan suatu teknologi akan bebas.

3. Attitude towards behavior

Attitude towards behavior atau sikap terhadap perilaku didefinisikan sebagai perasaan positif atau negatif tentang ketertarikan menggunakan sistem

4. Behavioral intention

Behavioral intention atauniat perilaku adalah suatu keinginan seseorang untuk melakukan suatu perilaku untuk melakukannya

5. Actual Tecnology

Tindakan yang dilakukan oleh seseorang, dalam konteks penggunaan sistem teknologi informasi perilaku adalah pengguna sesungguhnya.

Dalam penelitian ini teknik pengumpulan data yang digunakan adalah kuesioner. Teknik kuesioner merupakan suatu cara untuk memperoleh data langsung dari responden menggunakan daftar pertanyaan mengenai variabel-variabel yang diukur (Silalahi, 2009). Terdapat 5 instrumen yang digunakan untuk mengukur masing-masing variabel.Instrumen penelitian dikembangkan menggunakan skala Likert dengan 5 skala, skor terendah diberi nilai 1 dan tertinggi diberi nilai 5. Alternatif jawaban yang tersedia yaitu "sangat setuju", "setuju", "tidak setuju" dan "sangat tidak setuju". Skala Likert digunakan karena skala ini dapat mengungkapkan intensitas sikap/ perilaku atau perasaan responden (Silalahi, 2009).Hasil pengukuran dari skala Likert berupa data interval. Ukuran masing-masing indikator serta skala ukur dapat dilihat pada tabel dibawah ini: 
Tabel 2.

Kisi-kisi Instrumen Penelitian

\begin{tabular}{|c|c|c|c|}
\hline No & Konstruk & Indikator & $\begin{array}{l}\text { Skala } \\
\text { Ukur }\end{array}$ \\
\hline 1 & $\begin{array}{l}\text { Perceived } \\
\text { Ease of Use } \\
\text { (PEU) } \\
\text { Davis } \\
\text { (1989) dan } \\
\text { Chau } \\
(1996)\end{array}$ & $\begin{array}{l}\text { a. Kemudahan } \\
\text { dipelajari } \\
\text { b. Mudah } \\
\text { dipahami/dimen } \\
\text { gerti } \\
\text { c. Mudah sehingga } \\
\text { mahir } \\
\text { d. Mudah } \\
\text { digunakan } \\
\text { e. Mudah } \\
\text { dikendalikan } \\
\text { f. Mudah diingat } \\
\text { Davis (1989) dan } \\
\text { Chau (1996) }\end{array}$ & $\begin{array}{l}\text { Skala } \\
\text { Likert }\end{array}$ \\
\hline 2 & $\begin{array}{l}\text { Perceived } \\
\text { Usefulness } \\
\text { (PU) } \\
\text { Davis } \\
\text { (1989) dan } \\
\text { Chau } \\
(1996)\end{array}$ & $\begin{array}{l}\text { a. Lebih cepat } \\
\text { b. Meningkatkan } \\
\text { kinerja } \\
\text { c. Meningkatkan } \\
\text { produktivitas } \\
\text { d. Meningkatkan } \\
\text { efektivitas } \\
\text { e. Lebih mudah } \\
\text { f. Bermanfaat } \\
\text { Davis (1989) dan } \\
\text { Chau (1996) }\end{array}$ & $\begin{array}{l}\text { Skala } \\
\text { Likert }\end{array}$ \\
\hline 3 & $\begin{array}{l}\text { Attitude } \\
\text { Toward } \\
\text { Using } \\
\text { (ATU) } \\
\text { Davis } \\
(1989) \\
\end{array}$ & $\begin{array}{l}\text { a. Rasa senang } \\
\text { b. Menikmati } \\
\text { c. Rasa bosan } \\
\text { d. Tidak suka } \\
\text { Davis (1989) }\end{array}$ & $\begin{array}{l}\text { Skala } \\
\text { Likert }\end{array}$ \\
\hline 3 & $\begin{array}{l}\text { Behavioral } \\
\text { Intention } \\
(\mathrm{BI}) \\
\text { Davis } \\
(1989), \\
\text { Taylor dan } \\
\text { Tood (1995) }\end{array}$ & $\begin{array}{l}\text { a. Menggunakan } \\
\text { kapan saja } \\
\text { b. Menggunakan } \\
\text { kondisi apapun } \\
\text { c. Menggunakan } \\
\text { terus } \\
\text { d. Niat } \\
\text { menggunakan } \\
\text { terus } \\
\text { e. Berharap } \\
\text { menggunakan } \\
\text { Davis (1989), Taylor } \\
\text { dan Tood (1995) }\end{array}$ & $\begin{array}{c}\text { Skala } \\
\text { Likert }\end{array}$ \\
\hline 4 & $\begin{array}{l}\text { Actual } \\
\text { Usage (AU) } \\
\text { Igbaria et al } \\
(1995)\end{array}$ & $\begin{array}{l}\text { a. Penggunaan } \\
\text { sesungguhnya } \\
\text { b. Frekuensi } \\
\text { penggunaan } \\
\text { c. Kepuasan }\end{array}$ & $\begin{array}{l}\text { Skala } \\
\text { Likert }\end{array}$ \\
\hline
\end{tabular}

\begin{tabular}{|l|c|c|}
\hline & $\begin{array}{c}\text { pengguna } \\
\text { Igbaria et al (1995) }\end{array}$ & \\
\hline
\end{tabular}

Instrumen yang digunakan untuk penelitian harus berupa instrument yang valid. Instrument yang valid berarti dapat digunakan untuk mengukur apa yang seharusnya diukur (Sugiyono, 2013). Uji validitas dimaksudkan untuk mengukur kualitas kuesioner yang digunakan sebagai instrument penelitian. Instrument dikatakan valid jika instrument tersebut mampu mengukur apa yang diinginkan dan mengukap data yang diteliti secara tepat.

Analisis structural equation modeling (SEM) dengan program warpPLS digunakan untuk menguji hipotesis.Alat analisis statika ini dipilih karena mempunyai beberapa kelebihan (hair dkk, 2010).Pertama SEM-PLS sesuai untuk model penelitian ini yang menggunakan variabel yang tidak dapat diukur secara langsung (latent variabel) dan telah memperhitungkan measurement error.Kedua, analisis SEM dapat menguji secara simultan multiple dependence seperti dalam model penelitian ini.

\section{Validitas dan Reliabilitas Instrumen}

Validitas konvergen merupakan bagian dari measurement model yang dalam SEM-PLS biasanya disebut sebagai outer model sedangkan dalam covariance-based SEM disebut confirmatory factor analysis (CFA). Terdapat dua kriteria untuk menilai apakah outer model memenuhi syarat validitas konvergen untuk konstruk reflektif yaitu loading harus diatas 0,70 dan nilai $\mathrm{p}$ signifikan $<0,05$ (Hair dkk, 2013).

Uji realibilitas adalah pengujian yang dilakukan untuk mengukur sejauh mana suatu alat ukur dapat diandalkan.Dalam penelitian ini uji reliabilitas dilakukan dengan mengetahui apakah kuesioner yang dibagikan kepada responden memenuhi sehat reliabel.Reliabilitas dinilai dengan composite reliability dan cronbach alpha lebih besar dari 0,70.

\section{Menilai Kriteria Model Fit}

Uji kesesuaian antara model teoritis dan data empiris dapat dilihat pada tingkat (Goodness-of-fit statistic). Suatu model dikatakan fit apabila kovarians matriks suatu model adalah sama dengan kovarians matriks data. Model fit pada program WarpPLS dapat dilihat dari output general results untuk menilai berdasarkan model fit indices and $P$ values menampilkan hasil tiga indikator fit yaitu 
- Average path coefficient (APC) memiliki nilai $\mathrm{P}<0.05$

- $\quad$ Average R-Squared (ARS) memiliki nilai < 0,05

- Avarege variance inflation factor (AVIF) memiliki nilai $<5$

\section{Output Laten Variable Coefficients}

Koefisien determinasi menggunakan $R$-squared yang menunjukkan berapa persentase variansi konstruk endogen dapat dijelaskan oleh konstruk yang dihipotesiskan mempengaruhi eksogen.Semakin tinggi $R$-squared menunjukkan model yang baik.Q-squared merupakan ukuran nonparametik yang diperoleh melalui algoritma blindfolding.Q-squared digunakan untuk penilaian validitas prediktif atau relevansi dari sekumpulan variabel laten prediktor pada variabel kriterion. $Q$ squared analog dengan $R$-Squared namun hanya dapat diperoleh melalui resampling. $Q$-squared dapat bernilai negatif sedangkan nilai $R$-Squared selalu positif.

\section{Output Indirect and total effects}

Merupakan output penting khususnya dalam pengujian mediasi, kelebihan WarpPLS yang dapat membantu peneliti agar tidak repot secara manual untuk menghitung koefesien indirect effect dan signifikannya.

\section{DATA ANALYSIS AND DISCUSSION}

\section{Deskripsi Data}

Kuesioner diberikan kemahasiswa secara online dengan media sosial, kuesioner yang terkumpul 42.Responden yang ikut serta dalam pengisian kuesioner adalah mahasiswa akuntansi semester genap semua angkatan.

\section{Anlisis Data}

\section{Validitas dan Reliabilitas Instrumen}

Dari hasil olah data dengan menggunakan software warpPLS Terdapat dua kriteria untuk menilai apakah outer model memenuhi syarat validitas konvergen untuk konstruk reflektif yaitu loading harus diatas 0,70 dan nilai $\mathrm{p}$ signifikan $(<0,05)$ (Hair dkk, 2013).

Tabel 3.

Average variances extracted

\begin{tabular}{|c|c|c|c|c|}
\hline \multicolumn{5}{|c|}{ Average variances extracted } \\
\hline PEU & PU & ATU & BI & AT \\
\hline 0.738 & 0.740 & 0.798 & 0.728 & 0.742 \\
\hline
\end{tabular}

Sumber: Data diolah 2018

Dengan syarat tersebut, pengukuran konstruk telah memenuhi syarat validitas konvergen.
Pengujian selanjutnya adalah uji realibilitas konstruk yang dapat diukur dengan kriteria yaitu composite reliability dan cronbach's alpha. Suatu konstruk dinyatakan reliabel jika nilai composite reliability> 0,70. Berikut ini hasil dari output latent variable coefficients.

Tabel 4.

Composite reliability coefficients Composite reliability coefficients

\begin{tabular}{|c|c|c|c|c|}
\hline \multicolumn{5}{|c|}{ Composite reliability coefficients } \\
\hline PEU & PU & ATU & BI & AT \\
\hline 0.913 & 0.945 & 0.796 & 0.930 & 0.0896 \\
\hline
\end{tabular}

Sumber: Data diolah 2018

\section{Kriteria Model Fit}

Tabel 5.

Model fit indices and $P$ values

\begin{tabular}{|l|l|l|}
\hline $\begin{array}{l}\text { Average Path } \\
\text { Coefficient }\end{array}$ (APC) & 0.475 & $\mathrm{P}<0.001$ \\
\hline $\begin{array}{l}\text { Average R-Squared } \\
\text { (ARS) }\end{array}$ & 0.612 & $\mathrm{P}<0.001$ \\
\hline $\begin{array}{l}\text { Average Variance } \\
\text { Inflation } \\
(\text { AVIF) }\end{array}$ & 2.706 & Good if $<5$ \\
\hline
\end{tabular}

Sumber: Data diolah 2018

Nilai p untuk APC dan ARS lebih kecil dari 0.05 atau berarti signifikan.Selain itu, AVIF sebagai indikator multikolinearitas harus lebih kecil dari 5. Hasil output menunjukkan kriteria goodness of fit model telah terpenuhi yaitu dengan nilai APC sebesar 0.475 dan ARS 0.612 serta signifikan. Nilai AVIF sebesar 2.706 juga telah memenuhi kriteria.

\section{Ouput Laten Variable coefficients}

Tabel 6.

Output Laten Variable Coefficients

\begin{tabular}{|c|c|c|c|c|c|}
\hline & PEU & PU & $\begin{array}{c}\text { AT } \\
\text { U }\end{array}$ & BI & AT \\
\hline R-squared & & 0.67 & 0.53 & 0.69 & 0.54 \\
& & 4 & 8 & 1 & 6 \\
\hline Composite & 0.91 & 0.94 & 0.79 & 0.93 & 0.89 \\
reliab & 3 & 5 & 6 & 0 & 6 \\
\hline Cronbach's & 0.88 & 0.92 & 0.76 & 0.90 & 0.82 \\
alpha & 6 & 9 & 0 & 5 & 4 \\
\hline Avg.var.extrac & 0.63 & 0.74 & 0.59 & 0.72 & 0.74 \\
$\cdot$ & 8 & 0 & 8 & 8 & 2 \\
\hline Full Collin. & 3.38 & 3.98 & 2.47 & 4.30 & 2.70 \\
Vif & 5 & 8 & 3 & 0 & 0 \\
\hline Q-squared & & 0.67 & 0.56 & 0.70 & 0.56 \\
& & 8 & 5 & 6 & 3 \\
\hline
\end{tabular}

Sumber: Data diolah 2018 
Output pada tabel III di atas juga menyajikan dua ukuran reliabilitas instrumen penelitian yaitu composite reliability dan cronbach's alpha. Keduanya harus bernilai diatas 0,70 sebagai syarat reliabilitas (Fornell dan Lacker, 1981). Output diatas menunjukkan reliabilitas instrumen telah terpenuhi karena diatas 0.70.Average variance extracted(AVE) juga digunakan untuk vailiditas konvergen yang kriterianya harus diatas 0,50. Output menunjukkan kriteria tersebut telah terpenuhi.

\section{Output Indirect and total Effects}

Tabel 7.

Indirect and total Effects

\begin{tabular}{|c|c|c|c|c|c|}
\hline \multicolumn{6}{|c|}{ Indirect effects for paths with 2 segments } \\
\hline & PEU & PU & ATU & $\mathrm{BI}$ & $\mathrm{AT}$ \\
\hline \multicolumn{6}{|l|}{ PEU } \\
\hline \multicolumn{6}{|l|}{ PU } \\
\hline ATU & 0.267 & & & & \\
\hline BI & 0.600 & 0.123 & & & \\
\hline AT & -0.129 & 0.359 & 0.255 & & \\
\hline \multicolumn{6}{|c|}{ Number of paths with 2 segments } \\
\hline & PEU & PU & ATU & $\mathrm{BI}$ & AT \\
\hline \multicolumn{6}{|l|}{ PEU } \\
\hline \multicolumn{6}{|l|}{ PU } \\
\hline ATU & 1 & & & & \\
\hline BI & 1 & & & & \\
\hline AT & 1 & 1 & 1 & & \\
\hline \multicolumn{6}{|c|}{$\begin{array}{c}\text { P values of indirect effects for paths with } 2 \\
\text { segments }\end{array}$} \\
\hline & PEU & PU & ATU & $\mathrm{BI}$ & $\mathrm{AT}$ \\
\hline \multicolumn{6}{|l|}{ PEU } \\
\hline \multicolumn{6}{|l|}{ PU } \\
\hline ATU & 0.140 & & & & \\
\hline BI & $<0.001$ & 0.216 & & & \\
\hline $\mathrm{AT}$ & 0.315 & 0.011 & 0.042 & & \\
\hline
\end{tabular}

Sumber: Data diolah 2018

Output seperti tabel III merupakan output penting khususnya dalam pengujian mediasi. Tabel ini merupakan kelebihan WarpPLS yang dapat membantu peneliti agar tidak repot secara manual untuk menghitung koefesien indirect effect dan signifikansinya. Hasil estimasi menunjukkan bahwa pengaruh PEU terhadap ATU, BI dan AT secera tidak langsung adalah sebesar $0.267,0.600$ dan -0.129 .

\section{Uji Hipotesis}

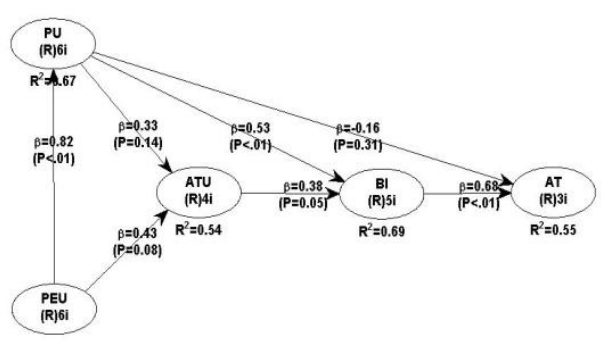

Gambar 2. Hasil Uji Hipotesis

Sumber: Data diolah 2018

H1: Persepsi kemudahan penggunaan (Perceived Ease of Use) berpengaruh terhadap persepsi kegunaan (Perceived Usefullnes) pada penggunaan E-learningdi POLJAM

Berdasarkan hasil pengolahan data diketahui nilai $\mathbf{P}<0.1$ atau dibawah $5 \%$ maka bisa dikatakan Perceived Ease of Use berpengaruh signifikan terhadap Perceived Usefullnes dengan besarnya pengaruh $R^{2}=0,67$ atau 67\%.Dengan demikian dapat dikatakan bahwa hasil hipotesis 1 penelitian ini diterima.

Hal ini sesuai dengan hipotesis dari penelitian Flourensius, (2017). Hipotesis Persepsi kemudahan penggunaan (Perceived Ease of Use) berpengaruh terhadap persepsi kegunaan (Perceived Usefullnes) diterima dengan besar pengaruh $\mathrm{R}^{2}=30 \%$

H2: Persepsi Kegunaan (Perceived Usefullness) berpengaruh positif terhadap sikap terhadap perilaku (Attitude Towards Using) penggunaan E-learningdi POLJAM

Berdasarkan hasil pengolahan data diketahui nilai $\mathbf{P}=\mathbf{0 . 1 4}$ atau diatas $5 \%$ maka bisa dikatakan Perceived Usefullness tidak berpengaruh signifikan terhadap Attitude Towards Using Dengan demikian dapat dikatakan bahwa hasil hipotesis 2 penelitian ini ditolak.

Pada hipotesis ke dua ini yaitu Persepsi Kegunaan (Perceived Usefullness) berpengaruh positif terhadap sikap terhadap perilaku (Attitude Towards Using) berbeda dari penelitian Flourensia, (2017) yang hipotesisnya ditolak.

H3: Persepsi kemudahan penggunaan (Perceived Ease of Use) berpengaruh terhadap sikap terhadap perilaku (Attitude Towards Using) pada penggunaan E-learningdi POLJAM Berdasarkan hasil pengolahan data diketahui nilai $\mathbf{P}=\mathbf{0 . 0 8}$ atau diatas $5 \%$ maka bisa 
dikatakan Perceived Ease of Usetidak berpengaruh signifikan terhadap Attitude Towards Using.Dengan demikian dapat dikatakan bahwa hasil hipotesis 3 penelitian ini ditolak.

Pada penelitian Flourensia, (2017) terkait hipotesis ke tiga ini diterima dan ini juga sejalan dengan penelitian surya ade saputra, (2017) yang hipotesisnya diterima

H4: Sikap terhadap perilaku (Attitude Towards Using) berpengaruh positif terhadap Niat perilaku (Behavioral Intention) pada penggunaan E-learningdi POLJAM

Berdasarkan hasil pengolahan data diketahui nilai $\mathbf{P}=\mathbf{0 . 0 5}$ atau tidak lebih dari $\mathbf{5 \%}$ maka bisa dikatakan Attitude Towards Using berpengaruh signifikan terhadap Behavioral Intention dengan besarnya pengaruh $\mathbf{R}^{2}=\mathbf{0 , 6 9}$ atau $69 \%$.Dengan demikian dapat dikatakan bahwa hasil hipotesis 4 penelitian ini diterima.

Pada hipotesis Sikap terhadap perilaku (Attitude Towards Using) berpengaruh positif terhadap Niat perilaku (Behavioral Intention) pada penelitian Flourensia, (2017) hipotesisnya diterima jadi hipotesis ke empat sama dengan penelitian terdahulu dengan besar pengaruhnya $\mathrm{R}^{2}=44 \%$.

H5: Persepsi kegunaan (Perceived Usefullnes) berpengaruh positif terhadap niat perilaku (behavioral Intention) penggunaan E-learningdi POLJAM

Berdasarkan hasil pengolahan data diketahui nilai $\mathbf{P}<0.1$ atau dibawah $5 \%$ maka bisa dikatakan Perceived Ease of Use berpengaruh signifikan terhadap Perceived Usefullnesdengan besarnya pengaruh $\mathbf{R}^{2}=0,69$ atau 69\%.Dengan demikian dapat dikatakan bahwa hasil hipotesis 5 penelitian ini diterima.

hipotesis ke lima ini hasilnya berbeda pada penelitian Flourensius, (2017) hasil hipotesisnya di tolak.

H6: Niat perilaku (behavioral Intention) berpengaruh terhadap Penggunaan nyata sistem (Actual system usage) penggunaan E-learningdi POLJAM

Berdasarkan hasil pengolahan data diketahui nilai $\mathrm{P}<0.1$ atau dibawah $5 \%$ maka bisa dikatakan behavioral intentionberpengaruh signifikan terhadap actual system usagedengan besarnya pengaruh $\mathbf{R}^{2}=0,55$ atau 55\%.Dengan demikian dapat dikatakan bahwa hasil hipotesis 6 penelitian ini diterima.

Pada hipotesis ini hasil penelitian Flourensius, (2017) diterima sama dengan penelitian ini dengan besar pengaruhnya $\mathrm{R}^{2}=94 \%$

H7: Persepsi Kegunaan (Perceived Usefullness) berpengaruh positif terhadap Penggunaan nyata sistem (Actual system usage) penggunaan E-learningdi POLJAM

Berdasarkan hasil pengolahan data diketahui nilai $\mathrm{P}=0.31$ atau dibawah $5 \%$ maka bisa dikatakan Perceived usefulnessberpengaruh signifikan terhadap actual system usage dengan besarnya pengaruh $\mathbf{R}^{2}=0,55$ atau 55\%.Dengan demikian dapat dikatakan bahwa hasil hipotesis 7 penelitian ini diterima.

Pada hipotesis ini hasil penelitiannya berbeda dengan Surya Ade Saputra, (2017) yang mana hasil penelitiannya di tolak.

Tabel 8

Rangkuman hasil pembuktian hipotesis

\begin{tabular}{|c|c|}
\hline Hubungan Varibael & Keterangan \\
\hline $\begin{array}{l}\text { H1: Perceived Ease of Use } \\
\text { berpengaruh terhadap Perceived } \\
\text { Usefullnes }\end{array}$ & Diterima \\
\hline $\begin{array}{l}\text { H2: Perceived Usefullness } \\
\text { berpengaruh terhadap Attitude } \\
\text { Towards Using }\end{array}$ & Ditolak \\
\hline $\begin{array}{l}\text { H3: Perceived Ease of Use } \\
\text { berpengaruh terhadap Attitude } \\
\text { Towards Using }\end{array}$ & Ditolak \\
\hline $\begin{array}{l}\text { H4: Attitude Towards Using } \\
\text { berpengaruh } \\
\text { Behavioral Intention }\end{array}$ & Diterima \\
\hline $\begin{array}{l}\text { H5: Perceived Usefullnes } \\
\text { berpengaruh terhadap behavioral } \\
\text { Intention }\end{array}$ & Diterima \\
\hline $\begin{array}{ll}\text { H6: } & \text { Behavioral } \\
\text { Intentionberpengaruh } & \text { terhadap } \\
\text { Actual system usage } & \\
\end{array}$ & Diterima \\
\hline $\begin{array}{l}\text { H7: Perceived Usefullness } \\
\text { berpengaruh terhadap Actual } \\
\text { system usage }\end{array}$ & Diterima \\
\hline
\end{tabular}

Sumber: Data diolah 2018

\section{CONCLUSION, IMPLICATION, SUGGESTION, AND LIMITATIONS}

Penelitian ini memiliki tujuh hipotesis yang diajukan, lima hipotesis dinyatakan diterima $\left(\mathrm{H}_{1}, \mathrm{H}_{4}, \mathrm{H}_{5}, \mathrm{H}_{6}, \mathrm{H}_{7}\right)$ dan dua hipotesis ditolak yaitu $\left(\mathrm{H}_{2}, \mathrm{H}_{3}\right)$. Dalam penggunaan E-learninguntuk proses pembelajaran penggunaannya telah merasakan 
manfaatnya. Hasil penelitian menunjukkan bahwa kemudahan penggunaan berpengaruh positif terhadap persepsi penggunanya yaitu teknologi.Akan tetapi berbanding terbalik penggunan teknologi tersebut terhadap sikap perilaku mahasiswa terhadap penggunaan sistem tersebut.Selanjutnya hasil penelitian menunjukkan bahwa sikap perilaku berperilaku berpengaruh positif terhadap niat perilaku.Dan niat perilaku mahasiswa dalam penggunaan Elearningmenunjukkan teknologi sesungguhnya. Penelitian ini memiliki beberapa keterbatasan yaitu tidak memperhitungkan variabel eksternal seperti Gender, Experience, complexity dan voluntariness.Oleh karena itu penelitian lanjutan perlu dilakukan dengan mempertimbangan faktor-faktor eksternal.Penelitian lanjutan dapat dilakukan dengan menguji penggunaan internet lainnya.

\section{REFERENCES}

Clark, Colvin, R., Richard, \& Mayer. (2011). Elearningand the Science of Instruction (Third Edit). San Francisco: Pfeiffer.

Davis, F.D, Bagozzi, R.P \& Warshaw. (1989). Acceptance of Computer Technology: A Comparison of Two Theoretical Models.

Dvorak, R. (2011). Moodle for Dummies. Indiana: Wiley Publishing.

Eko, S. (2011). Pengaruh Persepsi Kemudahan Dan Persepsi Kemanfaatan Terhadap Pemanfataan E-learningDengan Model TAM Di SMK Muhammadiyah 3 Yogyakarta. JBTI, Vol II, No.

Flourensia, et al, "Analisis Penerimaan e-learning Menggunakan Technology Acceptance Model (TAM) Studi Kasus: Universitas Atma Jaya Yogyakarta",JUTEI, vol.1, no. 2, 2017.

Jogiyanto. (2008). Sistem Informasi Keperilakuan. Yogyakarta: Penerbit Andi.

Rosenberg. (2002). Book review: Elearningstrategies for delivering knowledge in the digital age. Internet and Higher Education 2, $5,185-188$.

Rusman. (2012). Model-Model Pembelajaran. Depok: PT. Raja Grafindo Persada.

Sholihin, M., \& Ratmono, D. (2013). Analisis SEMPLS dengan WarpPLS 3.0. Penerbit Andi.

Silalahi, U. (2009). Metode Penelitian Sosial. Bandung: Refika Aditama.

Sugiyono. (2013). Metode Penelitian Kuantitatif, Kualitatif, dan RnD. Bandung: Alfabeta.

Surjono. (2013). Membangun Course E-
learningBerbasis Moodle. Yogyakarta: UNY Press.

Surya AS, et. al,"Analisis Penerimaan Sistem ELearning Menggunakan Technology Acceptance Model (TAM)", Jurnal Informasi Interaktif, Vol.2, no. 2, 2017. 